\title{
INVENTARISASI DAN INTENSITAS SERANGAN HAMA TANAMAN JERUK (Citrus sinensis L.) DI KECAMATAN SEKAMPUNG UDIK KABUPATEN LAMPUNG TIMUR
}

\section{INVENTORY AND INTENSITY OF ORANGE (Citrus sinensis L.) PEST ATTACK AT SEKAMPUNG UDIK DISTRICT EAST LAMPUNG REGENCY}

\author{
Yongky Lavia Foda ${ }^{1 *}$, Lestari Wibowo ${ }^{2}$, Puji Lestari², Rosma Hasibuan ${ }^{2}$ \\ ${ }^{1}$ Jurusan Agroteknologi, Fakultas Pertanian Universitas Lampung, Bandar Lampung, Indonesia \\ ${ }^{2} J u r u s a n$ Proteksi Tanaman, Fakultas Pertanian Universitas Lampung, Bandar Lampung, Indonesia \\ *Email:yongkylavia94@gmail.com \\ * Corresponding Author, Diterima: 10 Mei 2021, Direvisi: 7 Juni 2021, Disetujui: 29 Juli. 2021
}

\begin{abstract}
Orange fruit is very popular with the people of Indonesia, with a fresh taste, containing vitamin $C$ and has a selling power, as well as high economic value. Efforts to increase production can not be separated from the problem of plant pests on citrus plants, it is necessary to take serious handling of the pest problem. This study aims to inventory important pests of citrus plants and calculate the intensity of their attacks on citrus plants in Sekampung Udik District, East Lampung. The study was conducted in March 2019 to July 2019. The survey results in the villages of Gunung Pasir Jaya, Pugung Raharjo, and Sidorejo found 9 types of pests that attack citrus plants and there is 1 fruit damage due to climate. Pests - pests obtained are leaf pests (aphids, yellow icerya, leaf scrapers and leaf caterpillars), fruit pests (fruit borer and fruit fly), and twig pests (dompolan lice, stem borer and sikada). There is one factor that makes the fruit damaged / broken due to climate. The average level of pest attacks in the three study villages were aphids 3.67 colonies per branch, iceria yellow fleas 3.83 tails per branch, leaf slicer $3.46 \%$, leaf caterpillars $2.56 \%$, fruit borers 4, 44\%, 4.15 colonies per branch ticks, 0.01 stem borer per plant, 0.50 tails per branch. The highest intensity of pest attacks in three villages, namely fruit borer with the percentage of attacks of $4.44 \%$ of fruit attacked and the highest intensity of fruit borer infestation in Sidorejo village with a percentage of $4.51 \%$ of fruit attacked.
\end{abstract}

Keywords: Pests, attack intensity, inventory, oranges.

\begin{abstract}
ABSTRAK
Jeruk merupakan buah yang sangat digemari masyarakat Indonesia, dengan rasa yang segar, mengandung vitamin $\mathrm{C}$ dan memiliki daya jual, serta nilai ekonomis yang tinggi. Upaya peningkatan produksi tidak terlepas dari masalah organisme pengganggu tanaman (OPT) pada tanaman jeruk, maka perlu dilakukan penanganan yang serius pada masalah OPT. Penelitian ini bertujuan untuk menginventarisasi hama penting tanaman jeruk dan menghitung intensitas serangannya pada tanaman jeruk di Kecamatan Sekampung Udik Lampung Timur. Penelitian dilaksanakan pada bulan Maret 2019 hingga bulan Juli 2019. Hasil survei di Desa Gunung Pasir Jaya, Pugung Raharjo, dan Sidorejo ditemukan 9 jenis hama yang menyerang tanaman jeruk dan terdapat 1 kerusakan buah
\end{abstract}


akibat iklim. Hama - hama yang didapat yaitu hama daun (kutu daun, kutu icerya kuning, penggorok daun dan ulat daun), hama buah (penggerek buah dan lalat buah), dan hama ranting (kutu dompolan, penggerek batang dan sikada). Ada satu faktor yang membuat buah rusak / pecah dikarenakan iklim. Rata - rata tingkat serangan hama yang terdapat pada ketiga desa penelitian yaitu kutu daun 3,67 koloni per cabang, kutu icerya kuning 3,83 ekor per cabang, penggorok daun 3,46\%, ulat daun $2,56 \%$, penggerek buah 4,44 \%, kutu dompolan 4,15 koloni per cabang, penggerek batang 0,01 gejala per tanaman, sikada 0,50 ekor per cabang. Intensitas serangan hama paling tinggi di tiga desa yaitu hama penggerek buah dengan persentase serangan $4,44 \%$ buah terserang dan intensitas serangan hama penggerek buah tertinggi ada di desa Sidorejo dengan persentase $4,51 \%$ buah terserang.

Kata kunci : Hama, intensitas serangan, inventarisasi, jeruk.

\section{PENDAHULUAN}

Jeruk merupakan buah yang sangat digemari masyarakat Indonesia, dengan rasa yang segar, dan mengandung vitamin C. Buah jeruk ada berbagai macam jenis, yang paling terkenal dan diminatiadalah jeruk keprok dan jeruk manis. Jeruk yang saat ini dikembangkan di Indonesia terdiri dari beberapa jenis diantaranya jeruk manis dan sitrun yang berasal dari Asia Timur selain itu jeruk nipis, jeruk purut, jeruk bali yang berasal dari Asia Tenggara (Endarto \& Martini, 2016).

Jeruk memiliki daya jual dan nilai ekonomis yang tinggi sehingga di Indonesia tanaman ini sudah sekitar banyak dikembangkan, maka pemerintah tidak hanya mengarahkan pengelolaan jeruk bagi petani kecil tetapi juga mengorientasikan kepada pola pengembangan industri jeruk yang komprehensip termasuk dalam tanaman tahunan (BPTP Kaltim, 2011). Produksi buah jeruk di Indonesia pada tahun 2012, 2013, dan 2014 secara berturut-turut sebesar 1.498, 1548, dan 1.785 juta ton. Angka ini menunjukan terjadinya peningkatan produksi dari tahun 2012 hingga 2014 secara berturutturut sebesar 50.000 dan 236.000 ton (BPS, 2015).

Upaya peningkatan produksi tidak terlepas dari masalah pada akhir-akhir ini muncul masalah organisme pengganggu tanaman(OPT) pada tanaman jeruk (Kusdiana, 2017). OPT yang mengganggu tanaman jeruk dapat berupa hama daun, hama buah dan hama ranting atau batang. Jenis jenis OPT pada tanaman jeruk antara lain: ulat daun papilio (Papillo demolium), kutu-kutuan, lalat buah (Bactrocera sp), pengorok daun dan penggerek batang (Endarto \& Martini, 2016). Penanganan cepat merupakan salah satu cara yang dapat dilakukan untuk meningkatkan produksi. Sebelum melakukan upaya tersebut, terlebih dahulu perlu diketahui jenis-jenis hama yang menimbulkan kerusakan pada tanaman jeruk, sehinggan upaya pengendalian OPT yang akan dilakukan dapat efektif dan efisien. Untuk itu inventarisasi hama pada tanaman jeruk sangat perlu dilakukan.

\section{BAHAN DAN METODE}

Penelitian ini dilaksanakan ditiga desa yaitu Gunung Pasir Jaya, Pugung Raharjo, dan Sidorejo di Kecamatan Sekampung Udik Kabupaten Lampung Timur. Identifikasi hama yang diperoleh dilakukan di Laboratorium Hama dan Penyakit Tanaman Fakultas Pertanian, Universitas Lampung. Penelitian dilaksakan padabulan Maret 2019 hingga bulan Juli 2019. 
Bahan - bahan yang digunakan pada penelitian ini adalah hama - hama jeruk yang didapatkan dari hasil inventarisasidan alkohol 70\%. Alat-alatyang digunakan pada penelitian ini adalah gunting, cutter, stoples plastik,label, karet gelang dan loop,kamera, selotip, dan alat tulis.

Penelitian dilakukan menggunakan metode survei. Pengamatan dilakukan pada kebun jeruk yang telah menghasilkan buah ditiga desa yaitu Desa Gunung Pasir Jaya, Pugung Raharjo, dan Sidorejo. Pada setiap desa diamati tiga kebun jeruk, sehingga jumlah kebun jeruk yang diamati sejumlah 9 kebun. Pada setiap kebun diamati 10 tanaman sampel yang dipilih secara sistematik, dengan menarik garis diagonal pada bagian tengah kebun. Jarak anatara tanaman sampel $\pm 5 \mathrm{~m}$. Jumlah tanaman sampel yang diamati pada penelitian ini yaitu 90 tanaman jeruk.

Penelitian mengenai inventarisasi hama tersebut dilaksanakan dalam tiga tahap. Pertama adalah pengamatan secara langsung pada tamanan sampel, mengoleksi serangga hama yang ditemukan, dan identifikasi hasil koleksi di laboratorium.

Pengamatan dilakukan terhadap kerusakan pada tanaman yang diakibatkan oleh hama. Pengamatan dilakukan pada setiap unit sampel dengan menentukan empat cabang sebagai sub unit sampel. Cabang yang dipilih adalah cabang yang menuju arah utara, selatan, timur dan barat. Cabang yang diamati sebagai sub unit sampel sepanjang $60 \mathrm{~cm}$ dari ujung cabang. Seluruh bagian yang ada pada sub unit sampel (daun, buah, ranting) masuk dalam pengamatan.

Kerusakan yang teramati dicatat dalam tabel kemudian dihitung presentasinya. Serangga yang berada pada cabang sub unit sampel tersebut dikoleksi dan diberi label, untuk selanjutnya diidentifikasi di laboratorium. Pengamatan dilakukan pada pukul 07.00 -11.00 WIB. Selain cabang sebagai sub unit sampek yang diamati, batang utama juga diamati untuk melihat ada tidaknya serangan hama penggerek batang. Data hasil pengamatan terhadap hama-hama jeruk berupa persentase atau kepadatan populasi hama. Berikut metode pengamatan yang dilakukan.

a. Kutu Daun

Hama kutu daun pada tanaman jeruk ditemukan dalam koloni. Penghitungan kepadatan populasi hama kutu daun yaitu dengan menghitung jumlah koloni hama kutu daun per cabang sampel yang diamati.

\section{b. Kutu Dompolan}

Hama kutu dompolan pada tanaman jeruk melekat pada bagian cabang. Penghitungan kepadatan populasi hama kutu dompolan yaitu dengan menghitung jumlah kutu dompolan per ranting sampel yang diamati. c. Hama pengorok daun

Hama pengorok daun merusak bagian jaringan dalam daun dan menunjukan gejala yang khas. Penghitungan intensitas serangan hama pengorok daun adalah sebagai berikut:

Intensitas serangan $=\frac{\text { Jumlah daun terserang pada cabang sampel }}{\text { Jumlah daun pada ranting sampel }} X 100 \%$

\section{d. Hama penggerek buah}

Hama penggerek buah menyerang bagian buah dengan gejala yang khas dan cukup jelas yaitu adanya lubang gerek pada bagian kulit buah. Penghitungan intensitas serangan hama penggerek buah dihitung dengan cara : 
Intensitas serangan $=\frac{\text { Jumlah buah terserang pada cabang sampel }}{\text { Jumlah buah pada cabang sampel }} X 100 \%$ (2)

e. Ulat daun

Hama ulat daun menimbulkan gejala daun yang rusak termakan oleh ulat dengan menyisakan tulang daunnya saja. Perhitungan intensitas serangan hama ulat daun sebagai berikut:

Intensitas serangan $=\frac{\text { Jumlah daun rusak termakan ulat }}{\text { Jumlah daun pada ranting sampel }} X 100 \%$

\section{f. Lalat buah}

Hama lalat buah yang diamati pada saat pengamatan yaitu fase imago. Kepadatan populasi lalat buah dihitung dengan cara, jumlah imago lalat buah yang hinggap pada cabang sampel.

g. Buah rusak atau pecah

Pada saat pengamatan buah rusak akibat pengaruh iklim yang ekstrim. Intensitas buah rusak akibat iklim dihitung dengan cara:

Intensitas serangan $=\frac{\text { Buah rusak atau pecah pada cabang sampel }}{\text { Jumlah buah pada ranting sampel }} X 100 \%$ (4)

\section{HASIL DAN PEMBAHASAN}

Data hasil survei pada Tabel 1. terhadap tanaman jeruk di Desa Gunung Pasir Jaya, Pugung Raharjo, dan Sidorejo Kecamatan Sekampung Udik Kabupaten Lampung Timur ditemukan 9 jenis hama yang menyerang tanaman jeruk dan terdapat 1 kerusakan buah akibat iklim. Jenis hama yang ditemukan di semua lokasi terdapat 8 jenis yang sama yaitu kutu daun, kutu icerya kuning, pengorok daun, ulat daun, penggerek buah, lalat buah, kutu dompolan, dan sikada. Sedangkan hama penggerek batang hanya ditemukan pada satu tanaman yaitu didesa Sidorejo.
Intensitas serangan dari berbagai jenis hamahama jeruk terserbut berbeda - beda dari setiap lokasi. Data intensitas serangan hama jeruk pada desa Gunung Pasir Jaya dapat dilihat pada Tabel 2. Dari intensitas serangan berbagai jenis hama jeruk pada masing-masing desa merupakan hasil dari pengamatan dari tiga kebun sampel. Pada Tabel 3. hama kutu daun hidup berkoloni pada bagian tunas daun muda kepadatan populasi kutu daun di desa Gunung Pasir Jaya sebesar 3,44 koloni per cabang. Hama jeruk yang lain umumnya tingkat serangan cukup rendah kecuali hama yang langsung menyerang buah seperti hama penggerek buah. Hama penggerek buah intensitas serangannya sebesar $4,42 \%$. Meskipun intensitas serangan hama penggerek buah hanya sebesar $4,42 \%$ namun sudah cukup merugikan dan perlu untuk dilakukan tindakan pengendalian. Begitu pula kerusakan buah akibat cuaca ekstrim. Buah menjadi pecah selanjutnya akan gugur dan membusuk, kerusakan buah akibat iklim sebesar 6,13\%.

Pada Tabel 4. hama penggerek buah menyerang buah bagian dalam sehingga mengakibatkan buah busuk. Pada desa Pugung Raharjo intensitas serangan hama penggerek buah sebesar 4,39\% buah terserang, hama tanaman jeruk yang lain seperti kutu icerya kuning intensitas serangan sebesar 4,23 ekor per cabang dan kutu dompolan memiliki intensitas serangan sebesar 4,28 koloni per cabang. Serangan dari ketiga hama ini merupakan intensitas serangan tertinggi dari hama lain yang ditemukan

di tanaman jeruk pada desa Pugung Raharjo, sedangkan kerusakan buah dari cuaca ekstrim berakibat buah pecah hingga gugur dan membusuk mengakibatkan kerugian, maka perlu dilakukan tindakan pengendalian. 
Tabel 1. Jenis hama jeruk yang ditemukan pada pertanaman jeruk di desa Gunung Pasir Jaya, Pugung Raharjo, dan Sidorejo.

\begin{tabular}{|c|c|c|c|c|c|c|}
\hline \multirow{2}{*}{ No } & \multirow{2}{*}{ Nama Umum } & \multirow{2}{*}{ Ordo } & \multirow{2}{*}{ Spesies/Famili } & \multicolumn{3}{|c|}{ Desa } \\
\hline & & & & GPJ & $\mathrm{PH}$ & Sid \\
\hline 1 & Kutu daun & Hemiptera & Aphididae & + & + & + \\
\hline 2 & Kutu icerya kuning & Hemiptera & Icerya pulcher. & + & + & + \\
\hline 3 & Pengorok daun & Lepidoptera & Phyllocnistis citrela. & + & + & + \\
\hline 4 & Ulat daun & Lepidoptera & Papilio & + & + & + \\
\hline 5 & Penggerek buah & Lepidoptera & Citripestis sp. & + & + & + \\
\hline 6 & Lalat buah & Diptera & Tephritidae & + & + & + \\
\hline 7 & Kutu dompolan & Hemiptera & Pseudococcidae & + & + & + \\
\hline 8 & Penggerek batang & Coleoptera & Cossidae & - & - & + \\
\hline 9 & Sikada/ Lawana & Hemiptera & Lawana candida & + & + & + \\
\hline
\end{tabular}

Keterangan : GPJ = Gunung Pasir jaya, $\mathrm{PH}=$ Pugung Raharjo, $\mathrm{Sid}=$ Sidorejo

Tabel 2. Rata-rata intensitas serangan hama tanaman jeruk yang di Desa Gunung Pasir Jaya, Pugung Raharjo dan Sidorejo.

\begin{tabular}{lcccc}
\hline \multirow{2}{*}{\multicolumn{1}{c}{ Jenis hama }} & \multicolumn{3}{c}{ Desa } & \multirow{2}{*}{$\begin{array}{c}\text { Kepadatan populasi / Intensitas } \\
\text { Serangan }\end{array}$} \\
\cline { 2 - 4 } Kutu Daun & GPJ & PH & Sid & koloni per cabang \\
Kutu icerya Kuning & 3,44 & 3,90 & 3,68 & ekor per cabang \\
Pengorok Daun & 3,38 & 4,23 & 3,90 & $\%$ \\
Ulat Daun & 3,38 & 3,52 & 3,49 & $\%$ \\
Penggerek Buah & 2,56 & 2,56 & 2,57 & $\%$ \\
Kutu Dompolan & 4,42 & 4,39 & 4,51 & koloni per cabang \\
Penggerek Batang & 4,01 & 4,28 & 4,15 & gejala per tanaman \\
Sikada & 0 & 0 & 0,03 & ekor per cabang \\
\hline
\end{tabular}

Keterangan : GPJ = Gunung Pasir jaya, $\mathrm{PH}=$ Pugung Raharjo, $\mathrm{Sid}=$ Sidorejo

Pada Tabel 5. hama kutu icerya kuning pada bagian tunas daun muda intensitas serangan kutu daun di desa Sidorejo sebesar 3,90 ekor per cabang. Hama jeruk yang lain umumnya intensitas serangan cukup rendah kecuali hama yang langsung menyerang buah seperti hama penggerek buah. Hama penggerek buah intensitas serangannya sebesar 4,51\%. Meskipun intensitas serangan hama penggerek buah hanya sebesar 4,51\% namun sudah cukup merugikan dan perlu untuk dilakukan tindakan pengendalian. Begitu pula kerusakan buah akibat cuaca ekstrim. Buah menjadi pecah dan selanjutnya akan gugur dan membusuk, kerusakan buah akibat iklim sebesar.
Hama yang ditemukan merupakan hama yang menyerang bagian daun, buah dan ranting. Hama daun yaitu kutu daun, kutu icerya kuning, penggorok daun dan ulat daun. Hama buah yaitu penggerek buah dan lalat buah. Hama pada cabang yaitu kutu dompolan, penggerek batang dan sikada. Ada satu faktor yang membuat buah rusak / pecah dikarenakan iklim.

Dari berbagai jenis hama yang ditemukan menyerang jeruk di desa Gunung Pasir Jaya, Pugung Raharjo dan Sidorejo. Pada umunya pemilik kebun belum mengenal hama hama tersebut dan belum bisa menghitung intensitas serangannya. Pemilik kebun tidak melakukan tindakan apapaun yang mengakibatkan 
kerugian yang besar dari serangan hama tersebut.

Kutu daun yang ditemukan menyerang tanaman jeruk berada pada bagian ranting muda yaitu dibawah permukaan daun. Kutu ini hidup berkoloni. Satu koloni terdiri dari beberapa ekor. Kutu daun termasuk dalam ordo Hemiptera dan Family Aphididae. Kutu daun berukuran kecil, berbentuk oval, pipih dan berwarna hijau kehitaman. Tubuh kutu daun berukuran kecil dengan benjolan-benjolan pendek disepanjang sisi tubuh dan mengasilkan sekresi lilin berwarna putih. Serangan kutu daun menimbulkan gejala seperti pada bagian daun yang terserang menjadi kerdil dan keriting, biasanya ditandai dengan adanya semut dan embun jelaga yang berwarna hitam. Semut merupakan serangga simbion dari kutu daun sedangkan embun jelaga ini tumbuh karena adanya sekresi. Sekresi dari kutu daun kemudian menjadi media hidup bagi pertumbuhan jamur Capnodium sp. dengan demikian keberadaan kutu daun selain menghisap cairan tanaman juga menyebabkan adanya embun jelaga sehingga mengakibatkan pucuk daun berkerut dan tidak dapat tumbuh dengan baik. Rata-rata kepadatan populasi kutu daun pada Desa Gunung Pasir Jaya sebesar 3,44 koloni per cabang (Tabel3), pada desa Pugung Raharjo sebesar 3,90 koloni per cabang (Tabel 4) dan pada desa Sidorejo sebesar 3,68 koloni per cabang (Tabel 5).

Kutu Icerya kuning yang ditemukan dilapangan berada di bawah permukaan daun jeruk dan pada ranting pohon jeruk. Kutu Icerya kuning termasuk dalam ordo Hemiptera dan spesies Icerya pulcher yang punggungnya tertutup lilin kuning yang berguratgurat dan berbulu pendek. Kutu Icerya kuning

Tabel 3. Rata-rata intensitas serangan hama jeruk di Desa Gunung Pasir Jaya

\begin{tabular}{lccccc}
\hline \multirow{2}{*}{\multicolumn{1}{c}{ Jenis hama }} & \multicolumn{3}{c}{ Kebun ke- } & \multirow{2}{*}{ Rata-rata } & $\begin{array}{c}\text { Kepadatan populasi / Intensitas } \\
\text { serangan }\end{array}$ \\
\cline { 2 - 4 } & 1 & 2 & 3 & & koloni per cabang \\
Kutu daun & 3,45 & 3,55 & 3,3 & 3,44 & ekor per cabang \\
Kutu icerya kuning & 3,55 & 3,13 & 3,5 & 3,38 & $\%$ \\
Pengorok daun & 3,33 & 3,53 & 3,3 & 3,38 & $\%$ \\
Ulat daun & 2,43 & 2,58 & 2,7 & 2,56 & $\%$ \\
Penggerek buah & 4,48 & 4,93 & 3,9 & 4,42 & koloni per cabang \\
Kutu dompolan & 4,18 & 4,13 & 3,7 & 4,01 & gejala per tanaman \\
Penggerek batang & 0 & 0 & 0 & 0 & ekor per cabang \\
Sikada & 1,03 & 0,03 & 0,6 & 0,55 & \\
\hline
\end{tabular}

Tabel 4. Rata - rata intensitas serangan hama jeruk di Desa Pugung Raharjo

\begin{tabular}{|c|c|c|c|c|c|}
\hline \multirow{2}{*}{ Jenis hama } & \multicolumn{3}{|c|}{ Kebun ke- } & \multirow{2}{*}{ Rata-rata } & \multirow{2}{*}{$\begin{array}{c}\text { Kepadatan populasi / Intensitas } \\
\text { serangan }\end{array}$} \\
\hline & 1 & 2 & 3 & & \\
\hline Kutu daun & 4,2 & 4,13 & 3,4 & 3,90 & koloni per cabang \\
\hline Kutu icerya kuning & 4,6 & 4,35 & 3,7 & 4,23 & ekor per cabang \\
\hline Pengorok daun & 3,8 & 3,69 & 3,1 & 3,52 & $\%$ \\
\hline Ulat daun & 2,6 & 2,358 & 2,7 & 2,56 & $\%$ \\
\hline Penggerek buah & 4,1 & 4,455 & 4,6 & 4,39 & $\%$ \\
\hline Kutu dompolan & 4,2 & 4,551 & 4,1 & 4,28 & koloni per cabang \\
\hline Penggerek batang & 0 & 0 & 0 & 0 & gejala per tanaman \\
\hline Sikada & 0,8 & 0,025 & 0,9 & 0,55 & ekor per cabang \\
\hline
\end{tabular}


Tabel 5. Rata - rata intensitas serangan hama jeruk di Desa Sidorejo

\begin{tabular}{|c|c|c|c|c|c|}
\hline \multirow{2}{*}{ Jenis hama } & \multicolumn{3}{|c|}{ Kebun ke- } & \multirow{2}{*}{ Rata-rata } & \multirow{2}{*}{$\begin{array}{l}\text { Kepadatan populasi / Intensitas } \\
\text { serangan }\end{array}$} \\
\hline & 1 & 2 & 3 & & \\
\hline Kutu Daun & 3,85 & 3,725 & 3,45 & 3,68 & koloni per cabang \\
\hline Kutu icerya Kuning & 4,25 & 3,875 & 3,575 & 3,90 & ekor per cabang \\
\hline Pengorok Daun & 3,65 & 3,45 & 3,38 & 3,49 & $\%$ \\
\hline Ulat Daun & 2,53 & 2,55 & 2,63 & 2,57 & $\%$ \\
\hline Penggerek Buah & 4,53 & 4,18 & 4,83 & 4,51 & $\%$ \\
\hline Lalat Buah & 0,4 & 0,15 & 0 & 0,18 & ekor imago per cabang \\
\hline Kutu Dompolan & 4,20 & 4,08 & 4,18 & 4,15 & koloni per cabang \\
\hline Penggerek Batang & 0 & 0,1 & 0 & 0,03 & gejala per tanaman \\
\hline Sikada & 0,60 & 0,18 & 0,45 & 0,41 & ekor per cabang \\
\hline buah rusak / pecah & 5,4 & 5,95 & 5,875 & 5,74 & $\%$ \\
\hline
\end{tabular}

mengakibatkan daun jeruk menghitam sebagian atau seluruhnya karena menghisap sari daun serta ranting dan mengeluarkan cendawan jelaga. Kepadatan populasi hama kutu Icerya kuning di desa Gunung Pasir Jaya sebesar 3,38 ekor per cabang (Tabel 3), Desa Pugung Raharjo sebesar 4,23 ekor per cabang (Tabel 4) dan diDesa Sidorejo sebesar 3,90 ekor per cabang (Tabel 5).

Penggorok daun termasuk dalam ordo Lepidoptera dan spesies Phyllocnistis citrela yang menyerang daun dengan menggorok daun sehingga proses fotosintesis terganggu. Pada daun - daun jeruk yang muda terdapat liang korok berlingkar - lingkar yang berwarna putih berkilap kehijauan baik di bagian atas maupun di bawah daun, ulat ini menggorok daun jeruk muda yang membuat daun tersebut mengkerut dan bergulung memanjang sehingga tidak bisa tumbuh dengan sempurna yang akhirnya kering kemudian gugur sebelum waktunya dan berakibat kematian. Kepadatan populasi hama kutu daun di Desa Gunung Pasir Jaya sebesar 3,38 \% daun terserang per cabang

(Tabel 3), Desa Pugung Raharjo sebesar 3,52\% daun terserang per cabang (Tabel 4) dan Desa Sidorejo sebesar 3, 49\% daun terserang per cabang (Tabel 5).
Hama ulat daun yang ditemukan di lapang menyerang daun muda jeruk yang menggulung memanjang di dalamnya terdapat ulat muda yang berwarna kehijauan dengan kepala berwarna bercakkehitam. Ulat daun termasuk ke dalam ordo Lepidoptera, family Papilionidae dan sepsies papilio sp. Kepadatan populasi di Desa Gunung Pasir jaya sebesar 2,56\% daun terserang (Tabel 3), Desa Pugung Raharjo sebesar 2,56 \% daun terserang (Tabel 4) dan di Desa Sidorejo sebesar 2,57 \% daun terserang (Tabel 5).

Pada tanamanjeruk yang di temukan di lapang, buah jeruk terdapat lubang gerekan dan tampak tepung atau getah yang berada di sekitar lubang gerekan lalu buah tersebut membusuk akibat dari gerekan tersebut. Penggerek Buah termasuk ke dalam ordo Lepidoptera dan spesies Citripestis sp. Ulat yang berwarna merah kekuningan dengan kepala coklat hitam dan warna tubuh menjadi merah. Kemudian ulat mulai masuk ke dalam kulit buah dan hidup didalamnya hingga dewasa dengan mengeluarkan tepung atau getah yang berada diarea luar kulit jeruk, ulat akan terus menggerek buah tersebut hingga ke daging buah. Kepadatan populasi hama penggerek buah di Desa Gunung Pasir Jaya 
sebesar 4,42\% buah terserang (Tabel 3), di Desa Pugung Raharjo sebesar 4,39\% buah terserang (Tabel4) dan di Desa Sidorejo sebesar 4,51 \% buah terserang Tabel 5).

Lalat ini berukuran kecil berwarna coklat cerah. Buah jeruk yang terserang lalat buah mengalami bercak - bercak bulat busuk dengan sebuah lubang kecil ditengahnya dan di dalamnya terdapat belatung. Pada saat pengamatan hama lalat buah ditemukan dalam bentuk imago (serangga dewasa). Imago lalat buah ditemukan hinggap pada buah jeruk yang diamati. Imago lalat buah bersifat aktif bergerak dan terbang, sehingga kepadatan populasinya lalat buah dapat diamati dengan penggunaan perangkap namun dalam pengamatan ini tidak dilakukan penggunaan perangkap.

Kutu dompolan yang ditemukan di lapangan berwarna kuning muda tertutup lapisan lilin putih di sekujur tubuhnya dan hidup berkoloni deangan ukuran tubuh oval agak pipih. Kutu dompolan termasuk dalam ordo Hemiptera dan dan Famili Pseudococcidae. Kutu dompolan menyerang ranting muda, daun muda dan tangkai tangkai muda yang dihinggapi kutu secara bertumpuk tumpuk dengan menghisap sari daun dan mengeluarkan cendawan jelaga. Kepadatan populasi hama kutu dompolan pada desa Gunung Pasir Jaya sebesar 4,01 koloni per cabang (Tabel 3), di Desa Pugung Raharjo sebesar 4,28 koloni per cabang (Tabel 4) dan di Desa Sidorejo sebesar 4,15 koloni per cabang (Tabel 5).

Pada batang terdapat lubang yang tertutup dari kotoran ulat dan bubuk kayu yang terikat oleh benang sutera, kalau di angkat lubang pada batang kayu tersebut terdapat ulat yang bersembunyi. Penggerek batang termasuk ke dalam ordo Coeloptera dan famili Cossidae. Penggerek batang bagian batang jeruk, ulat

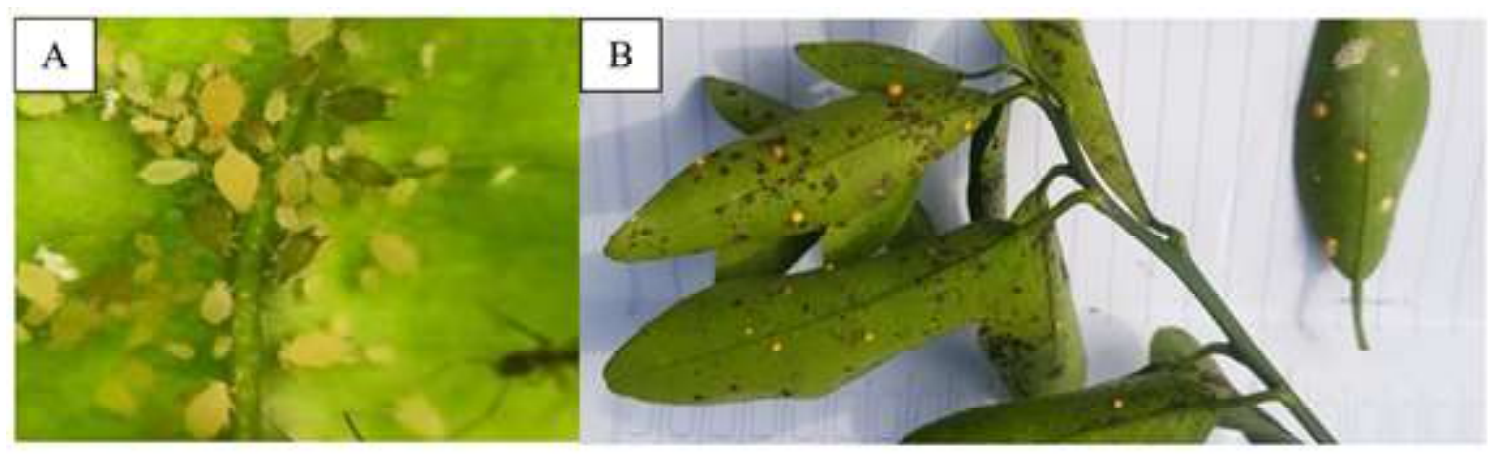

Gambar 1. a. Koloni kutu daun pada daun jeruk dan b. Kutu Icerya kuning

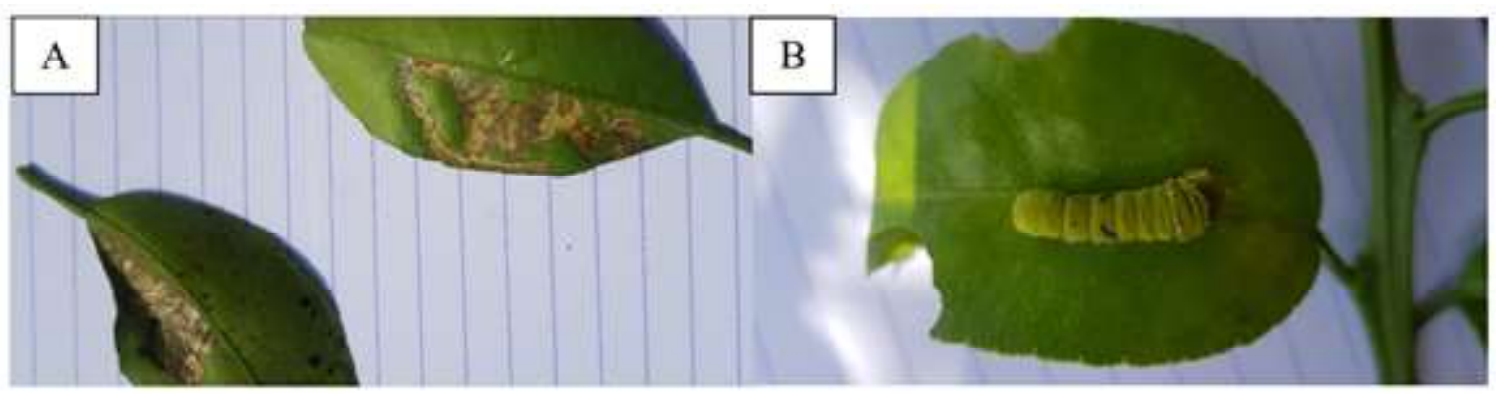

Gambar 2. a. Daun terkena Penggorok Daun dan b. Daun terserang Ulat Daun 


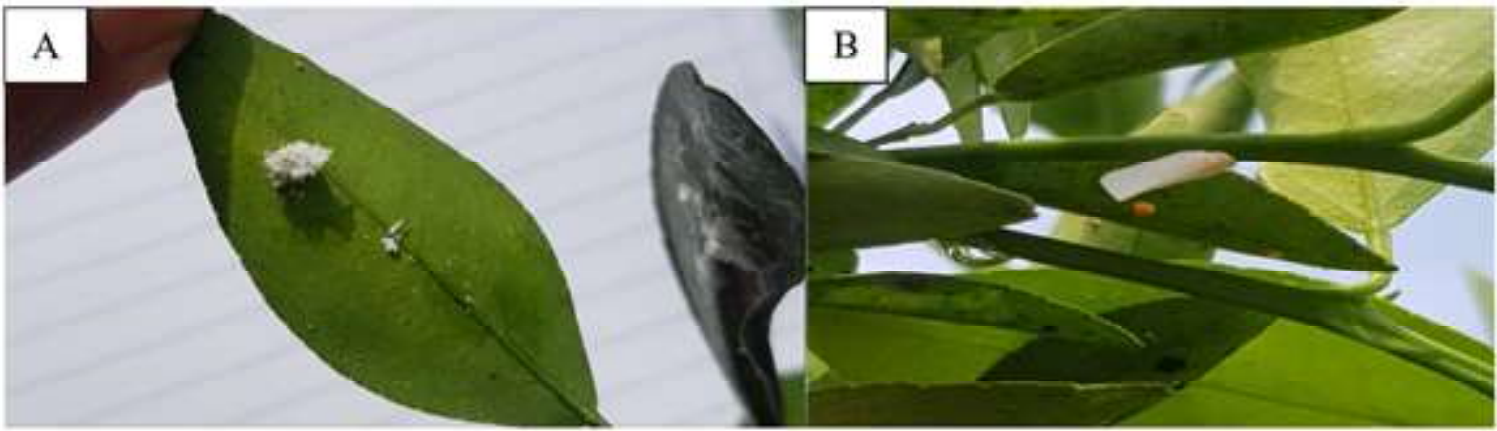

Gambar 3. a. Buah terserang Penggerek Buah dan b. Buah terserang Lalat Buah

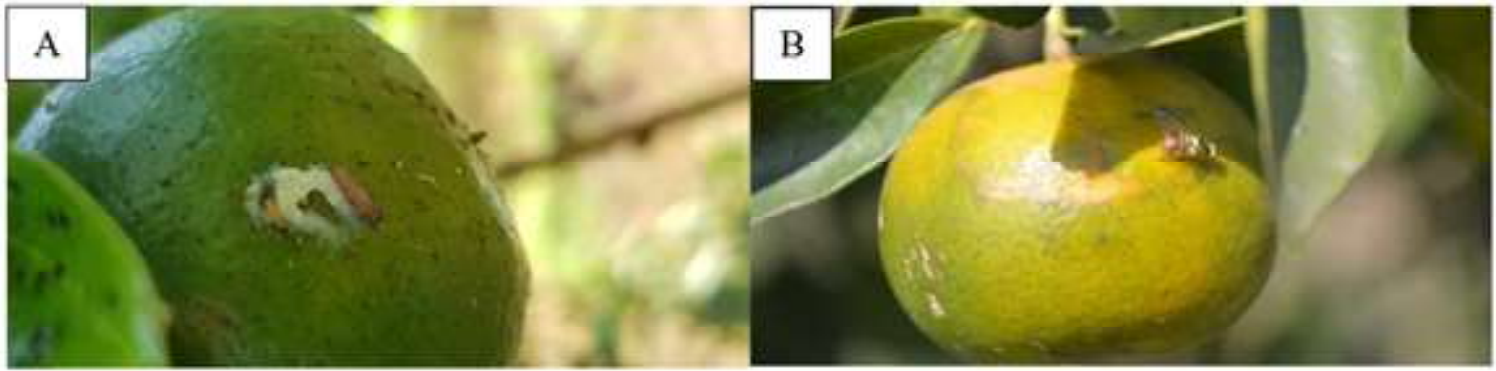

Gambar 4. a. Kutu Dompolan dan b. Sikada

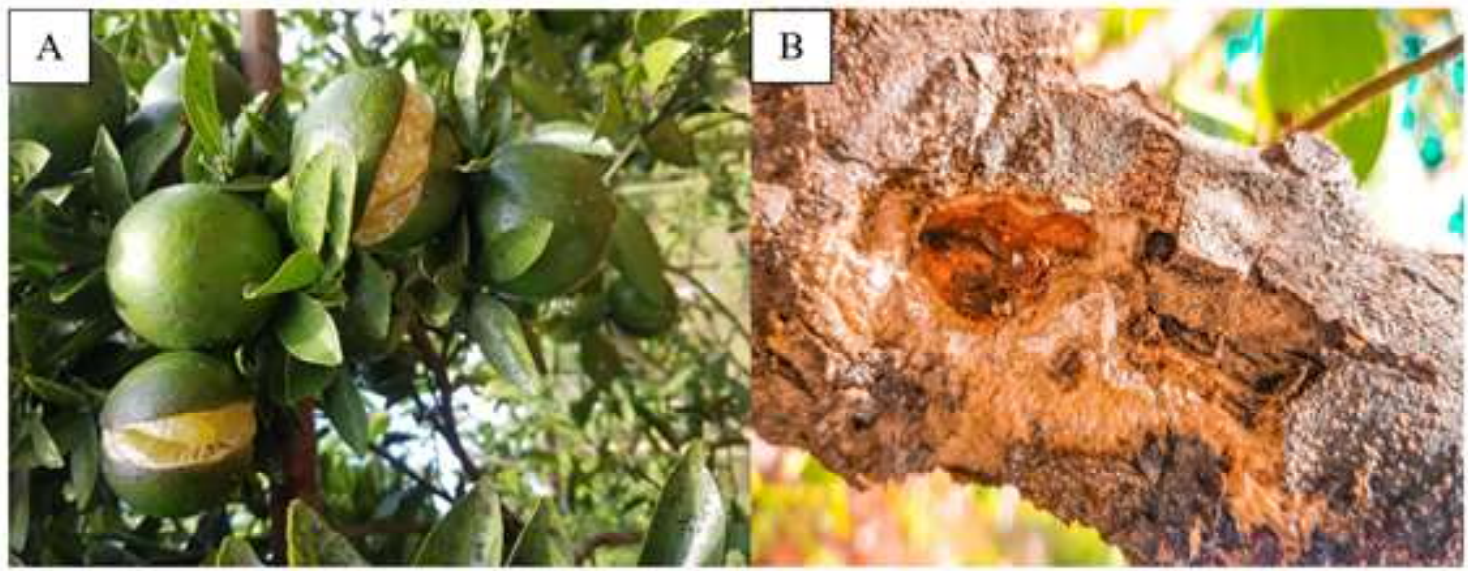

Gambar 5. a. Buah rusak/ percah dan Penggerek batang

yang menetas akan memakan bagian batang hinga membuat lubang panjang kedalam bagian batang sampai ke kambium. Kepadatan populasi hama ini terdapat 0,03 gejala per tanaman di Desa Sidorejo (Tabel 5).

Sikada menyerang ranting daun muda memudar dengan penuh lilin putih bagaikan kapas. Sikada termasuk ke dalam ordo Hemipter dan dan spesies Lawana candida. Kepadatan populasi di
Desa Gunung Pasir Jaya sebesar 0,55 ekor per cabang (Tabel 3), Desa Pugung Raharjo sebesar 0, 55 ekor per cabang (Tabel 4.) dan di Desa Sidorejo sebesar 0,41 ekor per cabang (Tabel 5).

Buah rusak / pecah diakibatkan oleh iklim yang berubah sangat ekstrim dari musim penghujan menjadi musim kemarau yang panas dan berkepanjangan yang mengakibatkan buah jeruk pecah seperti di desa Gunung 
Pasir Jaya ada 6,13\% buah / cabang (Tabel 3), Pugung raharjo 5,46\% buah / cabang (Tabel 4) dan Sidorejo $5,47 \%$ buah/cabang (Tabel 5).

Rata - rata intensitas serangan hama pada penelitian ini yang terdapat pada ketiga yaitu kutu daun sebesar 3,67 koloni per cabang, kutu icerya kuning sebesar 3,83 ekor per cabang, penggorok daun sebesar 3,46\% daun terserang per cabang, ulat daun sebesar 2,56\% daun terserang, penggerek buah sebesar 4,44\% buah terserang, buah rusak / pecah sebesar 5,78 \% buah / cabang, lalat buah sebesar 0,23 ekor imago per cabang, kutu dompolan sebesar 4,15 koloni per cabang, penggerek batang terdapat 0,01 gejala per tanaman, sikada sebesar 0,50 ekor per cabang. Dari semua hama yang sudah di dapat. Dengan demikian intensitas seranganhama di ketiga desa perlu mendapatkan penanganan yang cukup serius supaya tidak mengalami kegrugian.

\section{KESIMPULAN}

Berdasarkan hasil penelitian yang dilakukan, maka dapat di simpulkan bahwa, hama-hama jeruk yang ditemukan diketiga desa yaitu kutu daun, kutu icerya kuning, penggorok daun, ulat daun, penggerek buah, lalat buah, kutu dompolan, penggerek batang dan sikada. Selain itu Intensitas serangan hama daun jeruk pada tiga desa termasuk dalam tingkat serangan rendah namun intensitas serangan hama penggerek buah rata- rata 4,44\% sudah cukup merugikan dan sudah perlu dilakukan pengendalian.

\section{UCAPAN TERIMA KASIH}

Ucapan terima kasih disampaikan kepada seluruh Gapoktan Desa Gunung Pasir Jaya, Pugung Raharjo, dan Sidorejo Kecamatan Sekampung Udik Kabupaten Lampung Timur. Kepada dosen pembibing saya Ir. Lestari Wibowo, M..P. dan ibu Dr. Ir. Suskandini Ratih D., M.S. yang telah membimbing dan menemani survei penulis.

\section{DAFTAR PUSTAKA}

Badan Pusat Statistik (BPS). 2015. Produksi Buahbuahan dan Sayuran Tahunan di Indonesia. www.bps.go.id. Diakses tanggal 1 April 2019.

Badan Pengkajian Teknologi Pertanian Kalimantan Timur. 2011. Budidaya Jeruk Bebas Penyakit Kampung Tuban Kecamatan Tabalar Kabupaten Beraung. http://kaltim.litbang. deptan.go.id. Diakses 27 November 2019. Endarto, O \& E. Martini. 2016. Pedoman Budidaya Jeruk Sehat. World Agroforesty Centre (ICRAF) Southeast Asia Regional Progam. Bogor, 31 Desember 2016.

Kusdiana, B.D.P. 2017. Hama dan penyakit jeruk (Citrus spp.) di desa Situsari dan Karangsari Kecamatan Karang Pawitan Kabupaten Garut. (Skripsi). InstitutPertanian Bogor. Bogor. $53 \mathrm{hlm}$. 